\title{
Correction to: The economic thought of Federico Caffè and Paolo Sylos Labini on privileges and merit: a common ground with civil economy
}

\section{Gabriele Mandolesi $^{1}$}

Published online: 30 March 2021

(c) Springer-Verlag GmbH Germany, part of Springer Nature 2021

\section{Correction to: International Review of Economics https://doi.org/10.1007/s12232-021-00368-y}

In the original publication of the article, the production team processed reviewer's doc file as supplementary material file by mistake. Now, the incorrect supplementary material file was removed.

The original article has been corrected.

Publisher's Note Springer Nature remains neutral with regard to jurisdictional claims in published maps and institutional affiliations.

The original article can be found online at https://doi.org/10.1007/s12232-021-00368-y.

Gabriele Mandolesi

gamandolesi@gmail.com

1 Lumsa University, Rome, Italy 